\title{
Penerapan Implementasi Tata Kelola Pada Bank Syariah
}

\section{Muhammad Ismurroji}

Universitas Sumatera Utara, Indonesia

Corresponding Author: Ismuroji@gmail.com

\section{ABSTRACT}

Penulisan ini bertujuan untuk mengetahui pelaksanaan prinsip Good Corporate Governance pada Bank Syariah serta untuk mengetahui dan menemukan suatu formulasi yang berkaitan dengan strategi penerapan prinsip Good Corporate Governance pada Bank Syariah. Penulisan ini menggunakan Metode penelitian yang digunakan dalam penelitian ini adalah metode review jurnal. Metode pengumpulan data yang digunakan dalam penelitian ini yaitu dengan metode Studi Literatur

Keywords

Good Corporate Governance, Metode Review Jurnal, Studi Literatur

\section{PENDAHULUAN}

Tata Kelola Perusahaan (GCG) pertama kali diperkenalkan pada tahun 1998 di Indonesia. Tata kelola perusahaan (Corporate Governance) adalah interaksi antara agen dalam perusahaan dengan dewan perusahaan, prinsipal, dan stakeholder (OECD, 2015). Hubungan antara agen dalam perusahaan dengan dewan perusahaan, prinsipal, dan pemangku kepentingan ini diteliti melalui beberapa teori seperti teori agensi, teori stewardship, dan teori stakeholder. Good Corporate Governance (GCG) diperlukan untuk mendorong terciptanya pasar yang efisien, transparan serta konsisten dengan peraturan perundangundangan. Penerapan GCG perlu didukung oleh tiga pilar yang saling berhubungan, yaitu negara dan perangkatnya sebagai regulator, dunia usaha sebagai pelaku pasar, dan masyarakat sebagai pengguna produk dan jasa dunia usaha.

Penerapan tata kelola perusahaan yang baik (GCG) dalam sebuah perusahaan sangat penting sebagai salah satu proses untuk menjaga kesinambungan usaha perusahaan dalam jangka panjang yang mengutamakan kepentingan para pemegang saham (stakeholders) dan pemangku kepentingan (stakeholders). Penerapan prinsip GCG dalam dunia usaha saat ini merupakan tuntutan agar perusahaan-perusahaan tersebut dapat tetap eksis dalam persaingan global. Ada empat komponen utama yang diperlukan dalam konsep Good Corporate Governance, (Kaen,2003; Shaw, 2003) yaitu fairness, transparency, accountability, dan responsibility. Keempat komponen tersebut penting karena penerapan prinsip Good Corporate Governance secara konsisten terbukti dapat 
meningkatkan kualitas laporan keuangan dan juga dapat menjadi penghambat aktivitas rekayasa kinerja yang mengakibatkan laporan keuangan tidak menggambarkan nilai fundamental perusahaan.

\section{METODE PENELITIAN}

Metode Penelitian yang digunakan dalam penelitian ini adalah metode review jurnal. Metode pengumpulan data yang digunakan dalam penelitian ini yaitu dengan metode Studi Literatur. Pada metode Studi Literatur penulis akan mempelajari buku yang terkait dengan topik penelitian yang penulis pilih. Selanjutnya dalam metode ini penulis juga mencari jurnal atau penelitian terdahulu mengenai manajemen berbasis nilai untuk membantu penulis dalam pembuatan penelitian yang sedang berjalan.

\section{HASIL DAN PEMBAHASAN}

Prinsip Good Corporate Governance dalam Islam mengacu pada Alquran dan Hadits yang menjadikannya unik dan berbeda dengan konsep Good Corporate Governance dalam pandangan dunia barat. prinsip Good Corporate Governance dalam Islam menurut Muqorobin meliputi tauhid, taqwa dan ridha, equilibrium (keseimbangan dan keadilan), dan kemaslahatan. Prinsip-prinsip Corporate Governance dalam perspektif Islam diwujudkan melalui kerangka syariah dalam pelaksanaan bisnis, keadilan dan kesetaraan demi kemaslahatan serta berorientasi pada Allah SWT sebagai pemilik dan otoritas tunggal di dunia. Tauhid merupakan fondasi utama seluruh ajaran Islam. Tauhid menjadi dasar seluruh konsep dan seluruh aktifitas Umat Islam, baik dibidang ekonomi, politik, sosial maupun budaya (Nuruddin, 2012).

Guna menopang pengembangan operasional industri syariah di Indonesia keberadaan GGBS ini sangat penting untuk dikembangkan karena Pedoman Umum GGBS adalah acuan dalam berbisnis secara Islami, baik untuk lembaga yang sudah menyatakan diri sebagai entinitas syariah maupun yang belum. Hasilnya, bisnis yang dijalankan dengan governance yang baik akan lebih memungkinkan untuk tetap sustainable atau berlangsung secara baik sebab pedoman tersebut memberi petunjuk dalam cara menjalankan bisnis secara syariah. Harapannya, pengembangan bisnis syariah bukan hanya sekedar label saja tapi juga karakter diri dan identitasnya juga harus sesuai dengan tuntunan ajaran Islam. (Khariandy dan Malik, 2007)

Komite Nasional Kebijakan Governance (KNKG) menjelaskan bahwa dalam mendorong praktik bisnis syariah yang kuat dan sehat secara finansial dan senantiasa mengacu kepada prinsip-prinsip syariah, maka lembaga bisnis syariah diharapkan untuk melaksanakan prinsip-prinsip GCG berupa 
transparansi, akuntabilitas, tanggung jawab, kebebasan dan kewajaran dan juga kepatuhan kepada ketentuan-ketentuan syariah.

Semua pihak yang terkait dengan bisnis syariah harus memastikan bahwa asas GGBS dijadikan pijakan dasar bagi setiap aspek dan kegiatan usaha yang dilakukan. GGBS didasarkan atas pijakan dasar spiritual dan pijakan dasar operasional. Secara spiritual bisnis syariah harus berasaskan pada iman dan takwa yang diwujudkan dalam bentuk komitmen pada dua prinsip dasar yaitu halal dan tayib (baik). Prinsip halal dalam bisnis dilakukan dengan menghindari kegiatan bisnis yang dilarang diantaranya yaitu riba, maisir, gharar, zhulm, tabdzir, risywah, dan maksiat. Sedangkan Tayib meliputi dua aspek yaitu ihsan (melakukan atau memberikan yang terbaik dan menghindari perilaku yang merusak) dan tawazun (neraca keseimbangan dalam arti makro yang mencakup diantaranya keseimbangan antara spritual dan material, eksplorasi dan konservasi, sektor finansial dan sektor riil, risiko dan hasil) (Pedoman Good Governance Bisnis Syariah KNKG 2011).

\section{KESIMPULAN}

Penelitian ini dapat disimpulkan bahwa penerapan Good Corporate Governance (GCG) pada Bank Syariah sudah menjalankan dan menerapkannya dengan baik. Berdasarkan pada empat prinsip yang terdapat dalam Good Corporate Governance (GCG) yaitu Transparency (keterbukaan), Accouontability (akuntabilitas), Respobsibility (tanggungjawab) dan Fairness (kewajaran) yang sesuai dengan peraturan perundang-undangan yang diterapkan oleh Bank Indonesia. Prinsip-prinsip syariah yang mendukung pada Bank Syariah juga sudah dijalankan dan diterapkan dengan baik. Prinsip syariah tersebut adalah sifat nabi yang antara lain, shiddiq (kejujuran), amanah (kepercayaan), fathanah (kecerdasan) dan tabligh (keterbukaan).

\section{PENGAKUAN/ PENGHARGAAN}

Penulis ucapkan terima kasih kepada Universitas Sumatera Utara khususnya Fakultas Ekonomi dan Bisnis, serta kepada Dosen Perkuliahan Manajemen Keuangan Lanjutan Ibu Prof. Dr. Isfenti Sadalia, S.E, M.E atas segala ilmu-ilmu yang telah diberikan selama perkuliahan.

\section{REFERENCES}

Dewi, I. G. A. S., Endiana, I. D. M., \& Arizona, I. P. E. (2020). Pengaruh Leverage, Investment Opportunity Set (Ios), Dan Mekanisme Good Corporate Covernance Terhadap Kualitas Laba Pada Perusahaan 
Manufaktur Di Bursa Efek Indonesia. Kumpulan Hasil Riset Mahasiswa Akuntansi (KHARISMA),2(1), 125-136

Basri, Faisal dan Munandar, Haris. 2013. Lanskap Ekonomi Indonesia. Jakarta : Kencana Prenada Media Group

Azheri, Busyra. 2014. Corporate Social Responsibillity. Jakarta : PT Raja Grafindo Persada.

Sutedi, Adrian. 2017. Good Corporate Governance. Jakarta : Sinar Grafika.

Effendi, Arief. 2016. The Power of Good Corporate Governance Teori dan Implementasi. Jakarta : Salemba Empat

Bukhori. 2012. Pengaruh Good Corporate Governance dan Ukuran Perusahaan Terhadap Kinerja

Perusahaan. Skripsi. Universitas Diponegoro, Malang.

Prabowo, M Shidqon. 2018. Good Corporate Governance (GCG) dalam Prespektif Islam. Jurnal Ilmiah Ilmu Hukum QISTIE. Volume 11 (2)

Wilamarta Misahardi. 2005. Hak Pemegang Saham Minoritas dalam Rangka Good Corporate Governance, Cet. 2. Jakarta: Program Pascasarjana, Fakultas Hukum Universitas Indonesia 